\title{
構音評価における音響分析の意義
}

今泉 敏 ${ }^{11}$ 為川 雄二 ${ }^{2)}$ 出口 利定 ${ }^{2)}$ 伊藤 秀美 ${ }^{3)}$

要 約 : 視聴覚刺激を用いて英語 $/ \mathrm{r} /, / 1 /$ 音の識別訓練を行った日本語話者の英語および日 本語の構音動態を解析し, 構音と音, 音韻知覚の関係が, 言語によってかつ個々人の音韻概念 によって異なること, 成人であっても訓練によって変化し得ることを明らかにした. 病的構音 のコミュニケーション上の価值を評価する場合に構音と知覚の相互関係を配慮することが重要 であり，音響分析はそのために有用であることを論じた。

索引用語：構音, 音響分析, 知覚, 音韻概念, 脳の可塑性

\section{Acoustic Approaches for Assessment of Articulation}

Satoshi Imaizumi ${ }^{1)}$, Yuji Tamekawa ${ }^{2)}$, Toshisada Deguchi ${ }^{2)}$, Hidemi Ito $^{3)}$

\begin{abstract}
Audiovisual training in non-native speech discrimination was conducted on 10 native Japanese adults using audiovisual recordings of 14 native English speakers articulating $90 \mathrm{rl}$ word pairs, and analysis of changes in articulatory, acoustical, perceptual and cortical representations of native and non-native phonetic contrasts was performed. Results indicated that perceptual categorization of articulatory movements and resulting phonetic sounds is listener-dependent in a language-specific way, but categorization can be plastically modified even in adulthood through training. Based on these findings, the usefulness of acoustic approaches for proper assessment of communicative values of disordered articulations is discussed.
\end{abstract}

Key words : articulation, acoustic analysis, perception, phonetic categorization, cortical plasticity

\section{はじめに}

音声の解析では変動の多様性が常に問題になる。構 音やそれに対応する音響信号の解析では, 音韻の違い に直結する変動と, 話者の個性や感情, 態度に依存し た音韻には無関係な変動とを区別することが必ずしも
容易ではない，音韻の歪みや置換の原因となる構音動 態を突き止めるためにも，構音の変動のうちどれがど のような効果を持つかを知っておく必要がある．この 課題は音響分析によって構音の動態を知ろうとする場 合1)も避けて通ることは出来ない.

この課題はまた構音がどのように音韻として組織化

\footnotetext{
${ }^{1)}$ 東京大学医学系研究科認知・言語医学部門認知・言語行動科学分野：干 113-0033 東京都文京区本郷 7-3-1

${ }^{2)}$ 東京学芸大学教育学部： $\mathbf{T} 184-8501$ 小金井市貫井北町 4-1-1

${ }^{3)}$ 東北大学歯学部：干 980-8575 仙台市青葉区星陵町 $4-1$

${ }^{11}$ Department of Speech and Cognitive Sciences, Graduate School of Medicine, University of Tokyo : Bunkyo, Tokyo 113-0033

${ }^{2)}$ Tokyo Gakugei University : 4-1-1 Nukui-Kita-Machi, Koganei, Tokyo 184-8501

${ }^{3)}$ Tohoku University, School of Dentistry : 4-1 Seiryo, Aoba, Sendai 980-8575

原稿受理：2000 年 3 月 14 日
} 
されているかに関わっており，それは言語によって異 なっている.たとえば, 日本語話者にとって英語の/r/ と/1/音が区別できないという現象 ${ }^{2 \sim 13}$ は, これらの構 音の違いが音韻の違いに繫がらないという日本語に固 有の音韻体系に関わっている。「おばさん」と「おばー さん」を区別しない英語話者の特性もこれらの構音の 時間的差異を音韻の示差的特徵として採用しなかった 英語の特性に関わっている。一方の言語では音韻を変 えてしまう構音の差異が他方の言語においては音韻に 無関係な変動なのである。

英語の $/ \mathrm{r} /$ と/1/を区別できないのは「日本人の耳が 覀いからだ」という見解がある。しかし, 構音のわず かな違いを区別できる能力，つまり「良い耳」だけが 音声言語に必須な条件かどうかは疑わしい，われわれ の考えでは，構音の変化がどれほど大きくても同一音 韻内での変化ならばそれを無視し違いを聴かないとい う能力が，音韻という記号を用いたコミュニケーショ ンには必須である。つまり, 英語の $/ \mathrm{r} /$ と/ $/$ を区別しな いのは日本語では同一記号内の無視すべき変動だから であって「耳が悪い」からではない.高精度な聴覚的 弁別能力を携えて生まれてくる乳児が母語の音韻を獲 得するために最初に身につけるべき能力は, 違って聞 こえてしまう音でも記号として一つならその違いは無 視するという能力である ${ }^{14)}$. それが出来ないと構音を 音韻という記号として用いる音声コミュニケーション がそもそも成立しない.

このような見方に立つと，ある母語を自在に使いこ なすためには, 多様な構音（とそれに対応する音響信 号）のうち，その言語の音韻として検出すべき特性と 無視すべき特性とを無意識的にかつ自動的に選別でき る，そのような神経回路網を持つことが必要だという ことになる．そしてこの回路は言語に応じて個々人の 音韻概念の持ちょうに応じて異なってくる.

近年の観測技術の進展によって, 口の中の隠れた動 きであった構音もみえるようになった，ある構音運動 が音韻のどんな歪みや置換をもたらすのかを知ろうと すれば，構音をみることに加えて，その構音がどんな 音を作りどんな聞こえをもたらすのか，この言語と聞 き手の脳に依存する相互関係をいささかでも押さえて おく必要がある.

本論文では上記のような仮説を基線において，構音 評価における音響分析的方法の意義を論じた。具体的 には, 視聴覚刺激を用いて英語 $/ \mathrm{r} /, / 1 /$ 音の弁別訓練を 行った日本語話者の英語および日本語の構音動態をダ イナミック・パラトグラフと音響分析によって解析し, 構音と音響信号, さらに知覚特性との間の一様ではな
い関係を明らかにした．音響分析的に構音を評価する 場合にこの関係に配慮することが重要であることを論 じた.

\section{方 法}

予め英語 $/ \mathrm{r} /, / 1 /$ 識別訓練を識別率 $90 \%$ 以上になる まで行った日本人成人と, 訓練を全く受けていない日 本人成人，抢よび英語を母語とする米国人成人，それ ぞれ 4 名からダイナミック・パラトグラフと音声を同 時記録した。パラトグラムから各音韻間の接触パタン の違いを数值的に表す構音間距離を算出し, 得られた 音韻間距離マトリクスから多次元尺度構成法によって 各音韻の構音の遠近を表す構音地図を作成した。同様 に聴覚心理的方法で求めた各音韻間の知覚上の遠近を 表す知覚地図を算出した ${ }^{11}$. 音響分析では第 $1 \sim 3$ フ オルマント周波数軌跡を線形予測分析によって求め た. 方法の詳細は他で示した ${ }^{11 \sim 13)}$.

\section{結果}

図 1，2 亿は英語を母語とする米国人成人が発話し た right, light のダイナミック・パラトグラフとサウン ドスペクトログラムとを示す.図から明らかなように, 英語の $/ \mathrm{r} /$ では, 舌体の左右端を口蓋後部に接触させる のに対し, 英語/1/では舌体の前部を上歯茎部から硬口 蓋に広く接触させる．またサウンドスペクトログラム から明らかなように, 英語/ $\mathrm{r} /$ では第三フォルマント F 3 が低い值からゆっくりと後続母音の值に移行して いくに対して, 英語/1/では $3 \mathrm{kHz}$ に近い高い值から 始まり後続母音へ移るまでは比較的一定に保たれる。

図 3 には米国人成人が発話した語頭の r, l, w の第

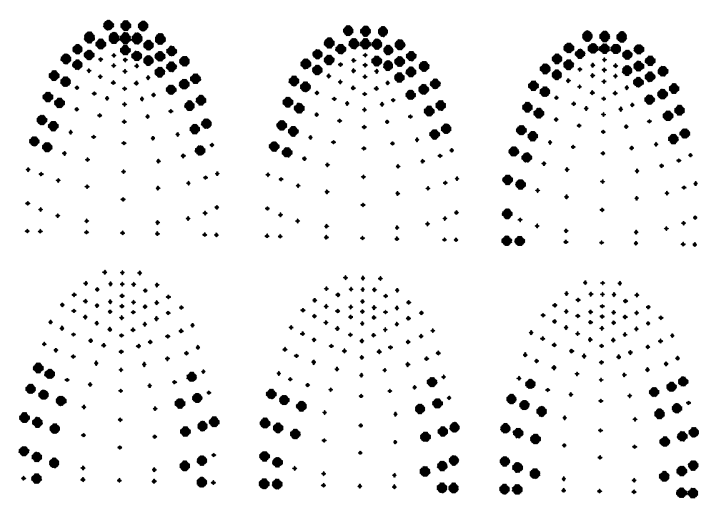

図 1 米国人成人が発話した light の/1/ (上) と right の/r/ (下) のダイナミック・パラトグラ フ. 各 3 回の発話の典型的な 1 パタンを示し た 


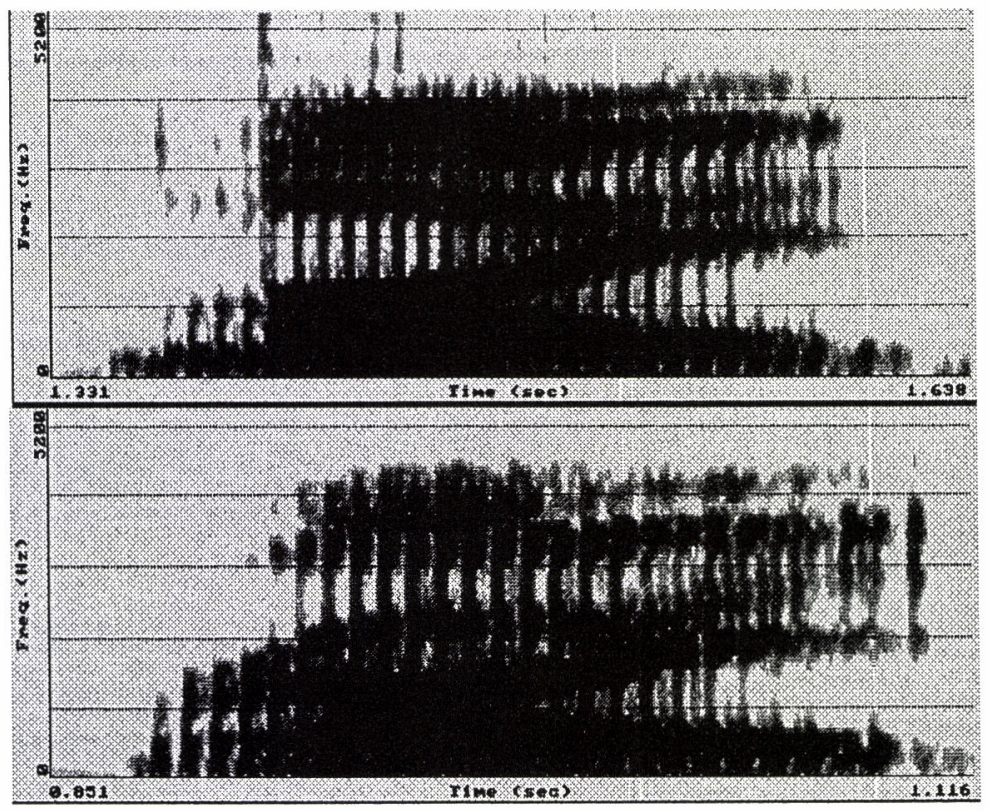

図 2 図 1 の中央のパラトグラフに対応する音声のサウンドスペクトログ

ラム（上が light, 下が right）

2,3 フォルマント周波数 (F 2, F 3 ) 平面上での 分布を示した。米国人 4 名に加えてカナダ人 10 名の データを集積した図である。図から明らかなように英 語話者のrでは第 3 フォルマントF３は低く，1では 高い. 両者はF 3 に対して対立的に分布する。 1 はF 2 で, r と 1 はF 3 で分離されることが分かる. 図 1 〜 3 から分かるように, 英語の $\mathrm{r}$ と 1 の構音とフ オルマント構造には大きな差異がある。

図 4 には訓練を受けた日本語話者 1 名に対して r， l 識別率の訓練による変化を示す。この訓練では英語話 者の顔面動画像と音声を提示して right, lightのよう に最小対立の関係にある 98 英単語の識別を行ったも のである．訓練当初，視聴覚情報を提示し識別を行う と $60 \%$ 代であった識別率は訓練とともに急速に上昇 した. $90 \%$ を越えた時点で, 視聴覚提示から恥覚のみ の提示に切り替えた。この時点で識別率は一旦低下し たものの，その後再び上昇し $98 \%$ 台で頭打ちになっ た.

このような結果は，1）訓練前にあつては構音とフ オルマント構造に大きな差異がある音韻であっても識 別が困難でありえること，2）構音動態を部分的にで も伝える視聴覚情報を使用した訓練によって識別の困 難な音韻であっても急速に識別可能になっていくこ と，3) 日本語話者であっても訓練によって $98 \%$ 台ほ どの高い識別率を獲得できることを示している。

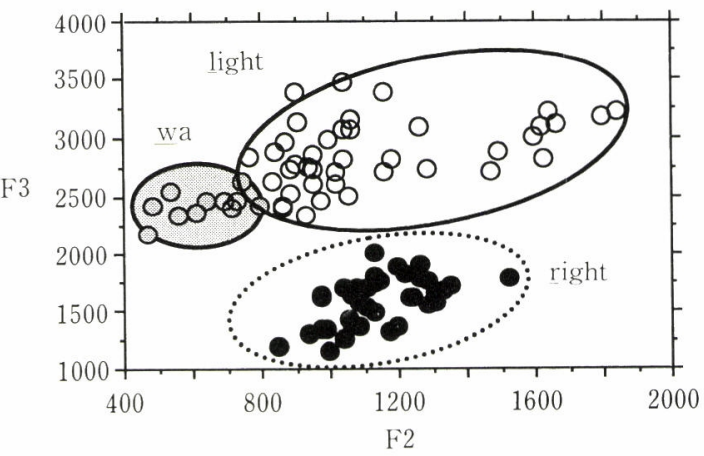

図 3 英語話者が発話した語頭の $\mathrm{r}, 1, w$ の第 $2 ， 3$ フォルマント周波数平面上での分布

図 5 (a)には，訓練を受けていない日本語話者 1 名に よる語頭に $/ \mathrm{r} /, / /$ 音を含む単語の構音地図を, (b)に, 訓練を受けた日本語話者 1 名のそれを各子音の代表的 なパラトグラムとともに示した。訓練を受けていない 日本語話者では, 英語/ $\mathrm{r} /$ 音の構音が非常に不安定で, 日本語 $/ \mathrm{r} /$ 音や英語/ $1 /$ 音と類似した構音を行っている ことが分かる。英語 $/ \mathrm{r} /, / 1 /$ 音の構音音が日本語 $/ \mathrm{r} /$ 音 に干涉されていると考えられる。一方，訓練を受けた 被験者は, 各子音とも比較的安定した構音を行ってお り，英語 $/ \mathrm{r} /, / 1 /$ 音と日本語 $/ \mathrm{r} /$ 音が明確に分離されて いる。パラトグラムから, 特に英語/ $\mathrm{r} /$ 音の調音が英語 話者のそれに類似しており, 日本語/ $\mathrm{r} /$ 音とは明確に異 


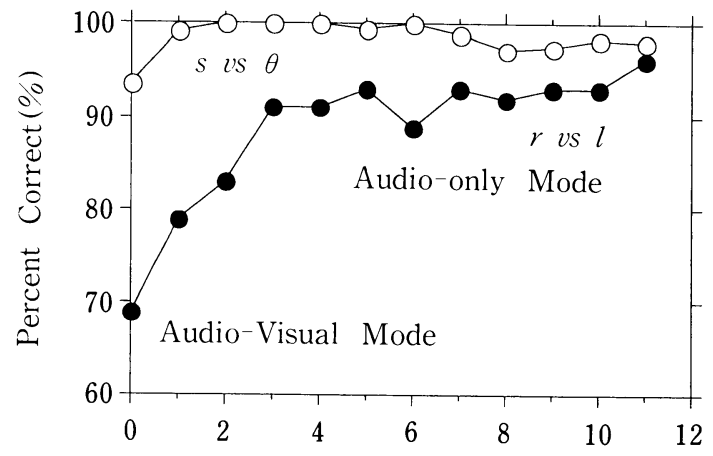

Session No.

図 4 訓練による r, 1 識別率の変化. Audio-Visual Modeでは視聴覚情報を, Audio-Only Mode では聴覚情報のみを提示した./s/と/ $/ /$ に対 する訓練結果も併せて表示してある

なった構音を行っていることが分かる。このことは, 4 ) $98 \%$ 台ほどの高い識別率を獲得できた話者では母 語話者に近い構音を獲得できることを示している。

図 6 には訓練前後の日本語話者が発話した right と light の語頭子音, および「ライト」,「ワイト」の語頭 子音の第 2,3 フォルマント周波数の分布を示した. 図から明らかなように日本語話者の「ライト」の語頭 子音は第 2 , 第 3 フォルマント平面上で右上がりの斜 めの楕円形状に分布する.つまり第 2 , 第 3 フォルマ ントは正の相関をもって分布する。「ライト」の語頭子 音のサンプルのうち, F 2 と F 3 がともに低いサンプ ルは英語の $\mathrm{r}$ と, 高いサンプルは 1 と共通の特性を持 つことになる.つまり, 英語の r と 1 の差異は「ライト」 の語頭子音の音韻を変えない変動になっている.

図 6 には訓練を受けた日本語話者が発話した right, light の語頭子音の第 2,3 フォルマント周波数の分布 も示した./r/の方は F 2 と F 3 がともに低く, 日本語 の「ら」からも遠くに分布しているのに対して,/1/は第 3 フォルマント軸上に広く分布し「ら」と重なる分布 になった。この結果は, 日本語話者にとって/r/は「ら」 との違いが構音的にも音響的にも明瞭であり習得が容 易であること, $/ 1 /$ は「ら」と違いが小さく習得がむし ろ難しいことを示唆している.

今回のパラトグラフの結果からみても, 英語 $/ \mathrm{r} /$ 音 は, 舌体の左右端を口蓋後部に接触するような形で調 音されるのに対し, 日本語/ $\mathrm{r} /$ のは舌尖を上歯茥部の裏 側に一瞬接触させる弾き音として構音されることが多 い. 日本語の $/ \mathrm{r} /$ は舌尖の動きは英語の $/ 1 /$ にむしろ近 い. 構音上はかなり異なる日本語と英語の音韻 $/ \mathrm{r} /$ が同 じ記号で表現され，類似している日本語/r/と英語/1/
が異なる記号で表現されている，このことが，日本語 話者の構音を混乱させる理由の一つになっているもの と考えられる.

以上の結果をまとめると，1）音響的特性が違う非 母語音韻を正確に識別できるかどうかは訓練効果の有 無, すなわち音韻概念の有無に依存していた。2）訓 練を受けていない日本語話者は, 日本語の $/ \mathrm{r} /$ と英語 の/r, l/を区別することが難しく, 構音上もこれらを安 定に分離することはできなかった。しかし，3）訓練 を受けた日本語話者では英語の/r, 1/を高精度で識別 することが可能になり，構音上も安定に区別でき，英 語話者の特性に近づいた４）この傾向は音響的特性 にも反映された。

\section{考 察}

今回の実験は，1）構音と知覚の関係は話者・聴者 の持つ音韻概念に依存した言語依存的なものであるこ と，2）そのために構音面でも音響面も大きな差異が ある音韻同士であっても知覚面では「区別しない」こ とがある得ること，3）音韻概念とそれに依存した構 音と知覚の特性は成人であっても訓練によって可塑的 に変化しえること,つまり母語以外の音韻概念を構音, 知覚両面で獲得できること, を示唆する。これらの結 果は本論文の最初に示した著者らの作業仮説に合致す る.

構音面でも音響面も大きな差異がある音韻同士であ っても知覚面では「区別しない」ことがあり得るとい う結果は，ある音韻の構音と音が健常者のそれとは大 きく異なっていてもなお知覚面では「問題がない」可 能性もあることも示唆している.たとえば口蓋裂があ ってロ腔内圧を上げることが困難なために, 咽頭部に 閉鎖を作って破裂音を代償的に生成する患者がいたと する。この場合精密には構音上も音としても歪ないし 置換にあたるであろうが，音声コミュニケーションは 成立する可能性がある. 代償的構音がその人の音韻体 系のどこにどう影響するかが重要な問題になる．だか ら, 構音の評価は構音だけを切り出して行うのではな く, 構音と音と, 聞こえの関係の中で, 音韻間の相互 関係を考慮して行うべきだとわれわれは考える.

構音検査における音響分析の第 1 の意義は, したが って, 構音と聞こえの関係をつなぐ道具としての意義 である、構音と音の関係は複雑である，そして音と知 覚の関係も言語に依存しかつ個々人の音韻概念に依存 する複雑な側面がある。このような複雑な関係は，構 音, 呼気流, 音, 知覚と段階をおって追求する方が分 かりやすい. 構音検査であっても, 構音と音と聞こえ 
Vol. 41 No. 2, 2000. 4

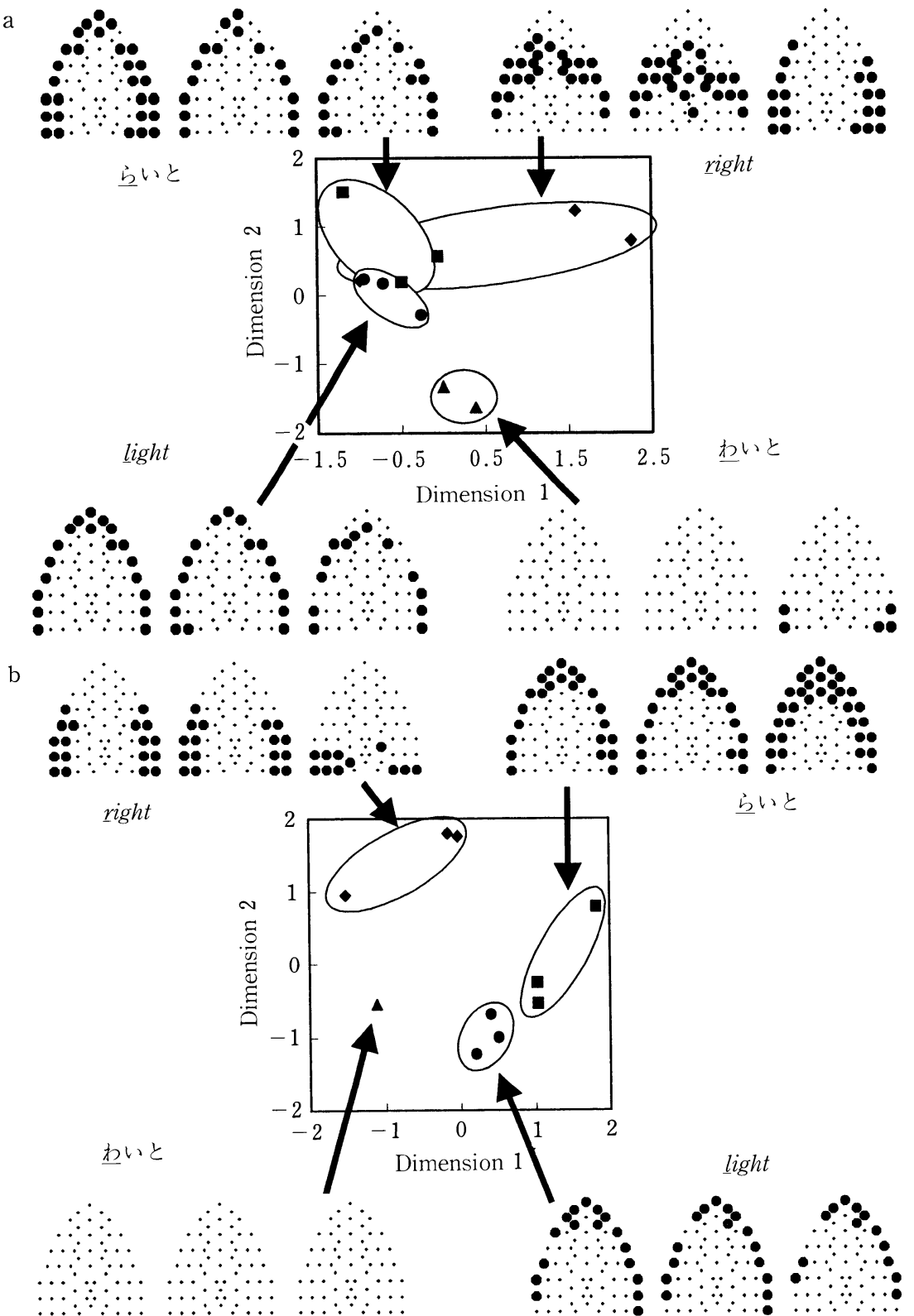

図 5 a : 訓練前日本語話者の構音地図, b : 訓練後日本語話者の構音地図

の関係の中で音韻間の相互関係の中で個々の構音を評 価した方がコミュニケーション上の問題をより深く理 解できると考える。

音韻概念が脳内でどのように表現されているかに関 してはなお議論の多いところである.われわれは構音, 音, 知覚, そして言語 (音韻間の相互関係) の諸側面 のマルチモーダル（聴覚, 視覚, 運動）な表象を繫ぐ
神経回路網を仮定する．本論文でみたように視聴覚識 別訓練によって構音が改良されるのはこの神経回路網 が訓練によって再構成されるからだと考える。この仮 説を支持する実験的データをわれわれはすでに他で示 した11〜13).

聴覚印象法 ${ }^{15,16)}$ で構音の歪みをある程度検出できる のはこの神経回路網を通して音（の聞こえ）から構音 


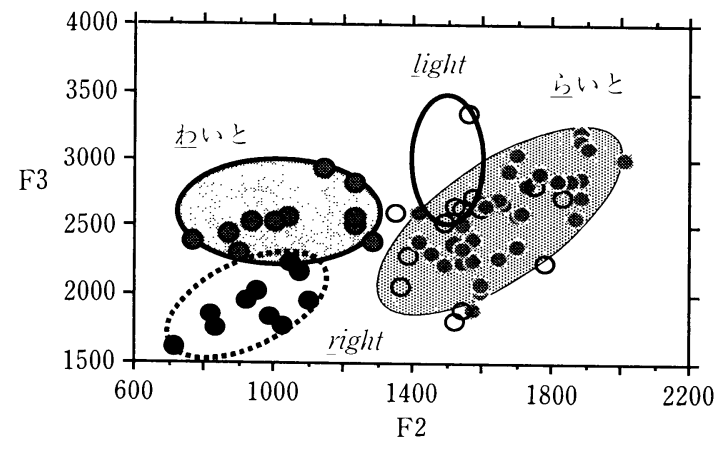

図 6 日本語話者の $/ \mathrm{r} /, / 1 /$ と「ライト」,「ワイト」の 語頭子音の第 2,3 フォルマント周波数の分布.

を推定することが可能だからである。しかし，本論文 でみたように構音, 音, 知覚の関係は言語に依存しか つ個々人の音韻概念（訓練の有無や上記の神経回路網 の有りよう）に依存する，健常人は健常な構音と聞こ えの概念に縛られて, 自分の音韻概念の土俵上で音と 構音の関係を判断することになる。自分の構音とは違 う, 障害を持った構音を音から正確に推定することは, したがって, 誰にでもどんな対象にでも常に可能なわ けではない.この制約を解決するためには, 構音運動 の観測に基づいて構音と音, 聞こえの相互関係をより 深く理解するよう, 自らの脳を鍛える必要がある.

本論文の結果は, 部分的にでも構音動態を知らしめ る視聴覚情報を使って音と構音と聞こえを繫ぐ神経回 路網を鍛えると，区別できなかった，あるいは区別し なかった音韻の聞こえも構音も区別できるようになる ことを示している．音韻概念とそれに依存した構音と 知覚の特性が成人であっても視聴覚的訓練によって可 塑的に変化しえるという結果は, デー夕に基づく訓練 の可能性を二重の意味で示唆する。一つは訓練を行う 側（言語聴覚士）の脳の可塑性であり，もう一つは訓 練を受ける患者側の可塑性である。

このように考えると, 構音検査における音響分析の 第 2 の意義は, 構音と音, 知覚の相互関係を引き出す ことによって, 検査を行う側はより正確に構音の問題 を把握できるようになり, 検査を受ける側は構音への より深い理解が得られて自らのことばを鍛える上げる ことに役立つと思える点である。

\section{文献}

1) Imaizumi, S., Fuwa, K., Hosoi, H. : Development of adaptive phonetic gestures in children : Evidence from vowel devoicing in two different dialects of Japanese. J. Acoust. Soc. Amer.,
$106(2):$ 1033-1044, 1999.

2) Goto, H. : Auditory perception by normal Japanese adults of the sounds "L" and "R". Neuropsychologia, 9:317-323, 1971.

3) Miyawaki, K., Strange, W., Verbrugge, R., et al: An effect of linguistic experience : the discrimination of $[\mathrm{r}]$ and [1] by native speakers of Japanese and English. Perception and Psychophysics, 18:331-340, 1975.

4) Mochizuki, M. : The identification of $/ r /$ and /l/ in natural and synthesized speech. J. Phonetics, $9: 283-303,1981$.

5) Best, C. T., McRoberts, G. W. and Sithole, N. N. : Examination of perceptual reorganization for nonnative speech contrasts : Zulu click discrimination by English-speaking adults and infants. J Exp Psychol: Human Perception \& Performance, 14 (3) : 345-360, 1988.

6) Logan, J. S., Lively, S. E. and Pisoni, D. B. : Training Japanese listeners to identify English $/ \mathrm{r} /$ and $/ 1 /:$ a first report. J. Acoust. Soc. Am., 89 (2) : 874-886, 1991.

7) Best, C. T. and Strange, W. : Effects of phonological and phonetic factors on crosslanguage perception of approximants. J. Phonetics, $20: 305-330,1992$.

8) Yamada, R. and Tohkura, Y. : The effects of experimental variables on the perception of American English $/ \mathrm{r} /$ and /1/ by Japanese listeners. Perception \& Psychophysics, 52(4): 376-392, 1992.

9) Lively, S. E., Logan, J. S. and Pisoni, D. B. : Training Japanese listeners to identify English $/ \mathrm{r} /$ and $/ 1 /$. II : The role of phonetic environment and talker variability in learning new perceptual categories. J. Acoust. Soc. Am., $94(3)$ : 1242-1255, 1993.

10) Flege, J. E., Takagi, N. and Mann, V. : Title Lexical familiarity and English-language experience affect Japanese adults' perception of $/ \mathrm{r}$ / and /1/. J. Acoust. Soc. Am., 99(2) : 1161-1173, 1996.

11) Imaizumi, S., Mori, K., Tamekawa, Y., et al. : Cortical plasticity in non-native speech perception : A MEG study. In Recent Advances in Biomagnetism (Edited by T. Yoshimoto et al., 
Tohoku University Press, Sendai, 1999) ,672675, 1999.

12）入江正明, 佐藤 裕, 出口利定, 他: 音韻概念形 成訓練による脳機能の変化. 教育科学, $50: 23-27$, 1999.

13）為川雄二, 今泉 敏, 御供理恵, 他：母語・非母 語調音の干渉：パラトグラフによる解析．信学技 法, SP 98-162：63-68, 1999.

14) Kuhl, P., Williams, K. A., Lacerda, F., et al : Linguistic experience alters phonetic perception in infants by 6 months of age. Science, 255(5044) : 606-608, 1992.
15）福迫陽子, 物井寿子, 辰巳 格, 他：麻痺性（運 動障害性）構音障害の話しことばの特徵一聴覚印 象による評価一。音声言語医学, $24: 149-164$, 1983.

16）福迫陽子, 遠藤教子, 紺野加奈江, 他：㾏攣麻痺 性構音障害患者の話しことばの変化一聴覚印象に よる評価一. 音声言語医学, 31：209-217, 1990.

別刷請求先： ₹ 113-0033 東京都文京区本郷 7-3-1 東京大学医学系研究科認知・言語医学部門 認知・言語行動科学分野 今泉 敏 